\title{
Universities can patent recombinant DNA results
}

THE RESULTS of university research using recombinant DNA techniques can be patented in the usual way, and do not require any special form of patent agreement, according to $\mathrm{Dr}$ Donald Frederickson, Director of the US National Institutes of Health.

The only proviso is that licences can be granted under patents secured on any invention only if the licensee provides an assurance that he or she will comply with the physical and biological containment standards laid down in the NIH guidelines for recombinant DNA research.

Dr Frederickson's decision, which was announced in Washington last week, follows eighteen months of discussion initially sparked off in 1976 by the decisions of Stanford University and the University of California to file a patent application on a process for forming recombinant DNA.

In deciding that no special patent machinery needs to be introduced to cover such research, Dr Frederickson has rejected the suggestions that since the research has potentially wide applications and has been financed largely from public funds, any patents arising from it should become the property of the US government.

This suggestion had received the support both of a number of scientists and other groups involved in the

\section{Spain keeps bargain- ing for European observatories}

Three nations involved in setting up astronomical observatories on prime Canary Island sites are discovering that the Spanish drive a bullish bargain. Last week scientific representatives of Denmark, Sweden, and the UK, all wishing to establish telescopes on Canary's high and dry peaks, met their Spanish counterparts for $2 \frac{1}{2}$ days of hard negotiations. There was substantial progress, but there remain equally substantial points of disagreement.

For the UK's project, the 'Northern Hemisphere Observatory' (NHO), it seems that the principal remaining argument is over the degree of commitment to Spanish astronomers and astronomy in the project. This is, indeed, the central scientific bargain in the whole scheme: that Spain will provide its observing sites, while participating countries will provide time and training facilities at the observatories to help develop Spanish recombinant DNA debate, and of the Department of Justice. The original version of the bill covering DNA research which Senator Edward Kennedy introduced into Congress last year-and later withdrew-was also based on the concept of government ownership of recombinant DNA inventions, although this was omitted in later versions of the bill.

In announcing his decision, Dr Frederickson said that comments received from individuals consulted by the NIH revealed general support for the existing institutional patent agreements (IPA) between the Depart-

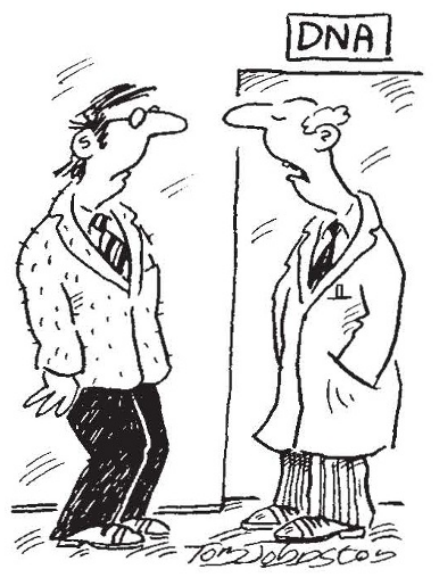

'We've developed a plasmid that forms the words "patent applied for",

astronomy. Other bargains, such as the extension of the Canary Islands road network, have already been struck.

The Spanish negotiators are presently arguing that a small amount of time which was to be reserved for international use should revert to bilateral use-divided equally between Spain and another country-and that training facilities for Spanish astronomers should extend to their being invited back to the home institutions of the collaborating groups in an observation. While this is clearly advantageous to the Spanish, it is seen as a difficulty on the other side of the table: observing time reserved for purely international use, is common at large observatories and it is not easy to impose controls, through the agreement, on the fellowship policy of the independent universities and institutions which would compose a collaboration.

Nevertheless these difficulties seem capable of resolution, and UK negotiators are speaking in terms of "a couple of months" before the heads of agreement are signed. Then the whole thing must be turned over to the foreign ministries-when other considerations might come into play quite ment of Health Education and Welfare and institutions receiving research grants through the NIH.

An IPA provides the institution carrying out a particular piece of research on department grants or contracts the first option to own all inventions arising from the research, although the government has to be granted a free non-exclusive licence to use the research results.

Dr Frederickson said that there were no compelling reasons to distinguish inventions arising from research involving recombinant DNA from others involving biological substances or processes that have been patented, even when partially or wholly developed with public funds.

"Such inventions include vaccines for rubella and rabies, treatments for herpes virus infections of the eye, treatments of uremia, and prostaglandins-compounds that may have a number of possible medical uses" Dr Frederickson said.

"The argument that commercial development based on patent protection has or will assure maximum benefits of these inventions to the public applies as well to the putative benefits of recombinant DNA inventions".

Under US law an inventor has a oneyear period of grace after research results are published in which to file for a patent.

David Dickson

outside the realms of astronomy, such as the status of the British colony of Gibraltar: If all went well, there might be agreement in a year.

\section{Big mirror for UK?}

A CHEAP ( $£ 1$ million) but large mirror blank resting tantalisingly in the works of Owens Illinois, the US optical firm, is giving concern to UK astronomers. Can they buy it for the large telescope planned for the Northern Hemisphere Observatory? The NHO is still a paper project, under negotiation with Spain for a site in the Canary Islands (see above). Finance has been agreed only for moving the cloud-bound 100-in Isaac Newton telescope, leaving the star of the show, a 4.2 metre light collector, unfunded. But with a blank of the right size waiting in Illinois at one-fifth the price a similar blank might fetch in a few years' time, it is tempting to buy it now. But that involves a commitment to the 4.2 metre telescope at some time in the future, and it is not clear that this will be forthcoming from the government. Negotiations continue. 